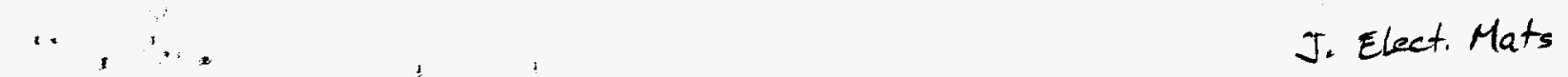

\title{
UV-PHOTOASSISTED ETCHING OF GaN IN KOH
}

Hyun $\mathrm{Cho}^{(1)}$, K.H. Auh ${ }^{(2)}$, J. $\operatorname{Han}^{(3)}$, R.J. Shul( ${ }^{(3)}$, S.M. Donovan ${ }^{(1)}$, C.R. Abernathy ${ }^{(1)}$, E.S. Lambers $^{(1)}$, F. Ren ${ }^{(4)}$ and S.J. Pearton ${ }^{(1)}$

${ }^{(1)}$ Department of Materials Science and Engineering

University of Florida, Gainesville FL 32611

${ }^{(2)}$ Department of Ceramic Engineering

Hanyang University, Seoul 133-791, Korea

RECEVED

DEC 871998

OSTI

${ }^{(3)}$ Sandia National Laboratories, Albuquerque NM 87185

${ }^{(4)}$ Department of Chemical Engineering

University of Florida, Gainesville FL 32611

\begin{abstract}
The etch rate of GaN under UV-assisted photoelectrochemical conditions in $\mathrm{KOH}$ solutions is found to be a strong function of illumination intensity, solution molarity, sample bias and material doping level. At low e-h pair generation rates, grain boundaries are selectively etched, while at higher illumination intensities etch rates for unintentionally doped $\left(\mathrm{n} \sim 3 \times 10^{16} \mathrm{~cm}^{-3}\right) \mathrm{GaN}$ are $\geq 1000 \AA \cdot \mathrm{min}^{-1}$. The etching is diffusionlimited under our conditions with an activation energy of $\sim 0.8 \mathrm{kCal} \cdot \mathrm{mol}^{-1}$. The etched surfaces are rough, but retain their stoichiometry.
\end{abstract}




\section{DISCLAIMER}

This report was prepared as an account of work sponsored by an agency of the United States Government. Neither the United States Government nor any agency thereof, nor any of their employees, make any warranty, express or implied, or assumes any legal liability or responsibility for the accuracy, completeness, or usefulness of any information, apparatus, product, or process disclosed, or represents that its use would not infringe privately owned rights. Reference herein to any specific commercial product, process, or service by trade name, trademark, manufacturer, or otherwise does not necessarily constitute or imply its endorsement, recommendation, or favoring by the United States Government or any agency thereof. The views and opinions of authors expressed herein do not necessarily state or reflect those of the United States Government or any agency thereof. 


\section{DISCLAIMER}

Portions of this document may be illegible in electronic image products. Images are produced from the best available original document. 


\section{INTRODUCTION}

The dissolution rate of semiconductors may be altered in acid or base solutions by illumination with above bandgap light. ${ }^{(1-8)}$ The mechanism for photo-enhanced etching involves the creation of e-h pairs, the subsequent oxidative dissociation of the semiconductor into its component elements (a reaction that consumes the photogenerated holes) and the reduction of the oxidizing agent in the solution by reaction with the photo-generated electrons. Generally, n-type material is readily etched under these conditions, while p-type material is not due to the requirement for confining photogenerated holes at the semiconductor-electrolyte interface.

Minsky et. al. ${ }^{(9)}$ reported the first photo-enhanced wet etching of n-GaN at room temperature in $\mathrm{HCl} / \mathrm{H}_{2} \mathrm{O}$ and $\mathrm{KOH} / \mathrm{H}_{2} \mathrm{O}$ solutions. A He-Cd laser with typical energy density $\sim 0.6 \mathrm{~W} \cdot \mathrm{cm}^{-2}$ was employed to create $\mathrm{e}-\mathrm{h}$ pairs, and rates up to a few thousand angstroms per minute were obtained. Youtsey et. al. ${ }^{(10-14)}$ employed a broad-area Hg lamp and $\mathrm{KOH}$ solutions to demonstrate dopant-selective photo-enhanced wet etching of $\mathrm{n}$ GaN. Ti metal contacts provided electrical contact to the GaN, while a Pt wire was used as the system cathode. Smooth etching was achieved under high light intensity, low $\mathrm{KOH}$ concentration conditions. Strong evidence was found that the dislocation microstructure could be revealed by selective etching of material between dislocations. ${ }^{(14)} \mathrm{Lu}$ et. al. ${ }^{(15)}$ reported photo-assisted anodic etching of $\mathrm{n}-\mathrm{GaN}$ in tartaric acid/ethylene glycol solutions at room temperature, with rates up to $1600 \AA \cdot \mathrm{min}^{-1}$. Peng et. al. ${ }^{(16)}$ were able to use aqueous $\mathrm{H}_{3} \mathrm{PO}_{4}$ and $\mathrm{KOH}$ solutions with $\mathrm{UV}$ illumination to etch $\mathrm{GaN}$. The etch rates were strongly dependent on the $\mathrm{pH}$ value of the solutions, peaking at $\sim 1000-1200 \AA \cdot \mathrm{min}^{-}$

${ }^{1}$ for $\mathrm{pH}$ of 1 for $\mathrm{H}_{3} \mathrm{PO}_{4}$ and 14 for $\mathrm{KOH}$. The photoelectrochemical process was found to 
create $\mathrm{Ga}_{2} \mathrm{O}_{3}$ on the $\mathrm{GaN}$ surface, that was subsequently dissolved by the acid or base solution. Pulsed electrochemical etching with $\mathrm{H}_{3} \mathrm{PO}_{4} /$ ethylene glycol/ $/ \mathrm{H}_{2} \mathrm{O}$ solutions was found to etch both $\mathrm{p}-\mathrm{GaN}$ and the InGaN active region in light-emitting diode structures, providing a simple and controlled method of exposing the underlying n-GaN for contacting. ${ }^{(17)}$

Conventional wet etching without photo- or current-enhancement has proven relatively ineffective for $\mathrm{GaN} .{ }^{(18)}$ Molten $\mathrm{KOH}$ and elevated temperature $\mathrm{H}_{3} \mathrm{PO}_{4}$ has been reported to produce etch pits on $\mathrm{GaN}^{(19,20)}$, and Stocker et. al. ${ }^{(21)}$ have used similar solutions in glycol at typical temperatures of $\sim 180^{\circ} \mathrm{C}$ to produce well-defined crystallographic etching of wurtzite $\mathrm{GaN}$. Kim et. al. ${ }^{(22)}$ found that $\mathrm{H}_{3} \mathrm{PO}_{4}, \mathrm{NaOH}$ and $\mathrm{KOH}$ solutions at these temperatures are useful for removing $\mathrm{N}_{2}$-deficient surface layers on GaN induced by processes such as high temperature annealing or dry etching. After removal of this damaged material, selective etching began to reveal etch pits.

In this paper we report on some of the characteristics of photo-assisted etching of $\mathrm{GaN}$ in $\mathrm{KOH}$ solutions, as a function of UV illumination intensity, $\mathrm{KOH}$ concentration and solution temperature. The etch rates increase strongly when the samples are biased during light exposure. No etching of degenerately-doped $\operatorname{InN}\left(\mathrm{n} \sim 10^{20} \mathrm{~cm}^{-3}\right)$ was obtained under our conditions.

\section{EXPERIMENTAL}

GaN layers $\sim 2 \mu \mathrm{m}$ thick were grown on $\mathrm{Al}_{2} \mathrm{O}_{3}$ substrates at $1040^{\circ} \mathrm{C}$ by Metal Organic Chemical Vapor Deposition. Both $\mathrm{n}^{+}\left(\mathrm{n} \sim 3 \times 10^{18} \mathrm{~cm}^{-3}\right)$ and unintentionally doped $\left(\mathrm{n} \sim 3 \times 10^{16} \mathrm{~cm}^{-3}\right)$ layers were used in these experiments. InN layers $\sim 1 \mu \mathrm{m}$ thick were 
grown on $\mathrm{Al}_{2} \mathrm{O}_{3}$ at $\sim 650^{\circ} \mathrm{C}$ by Metal Organic Molecular Beam Epitaxy. These films are degenerately n-type $\left(\sim 10^{20} \mathrm{~cm}^{-3}\right)$ due to residual defects or impurities. Ti metal contacts were patterned by lift-off on the periphery of the samples, and etching performed in a standard electrochemical cell consisting of a tefion sample holder and a $\mathrm{Pt}$ wire cathode $^{(2-6,9-14)}$ An unfiltered $450 \mathrm{~W} \mathrm{Hg}$ arc lamp $\sim 15 \mathrm{~cm}$ from the sample provided illumination of the samples, which were immersed in unstirred $\mathrm{KOH}$ solutions. Etch depths were measured by stylus profilometry, while the surface morphology was examined by both scanning electron microscopy (SEM) and tapping mode atomic force microscopy (AFM). The near-surface stoichiometry was examined by Auger Electron Spectroscopy (AES).

\section{RESULTS AND DISCUSSION}

For low Hg lamp powers ( $\leq 100 \mathrm{~W}$ ), we did not observe any macroscopic etching of the $\mathrm{GaN}$ (or $\mathrm{InN}$ ), but there was selective etching at grain boundaries to reveal the hexagonal nature of the GaN (Figure 1). This would be expected since the defective regions should contain a higher density of dangling or weakened atomic bonds that are more readily attacked by the $\mathrm{KOH}$ than the lower defect density material in between grains.

At higher lamp powers significant etch rates were obtained for both types of $\mathrm{GaN}$ used, as shown in Figure 2. As the $\mathrm{KOH}$ solution molarity increases, the etch rates of both $\mathrm{n}$ and $\mathrm{n}^{+} \mathrm{GaN}$ increase, and then saturate before decreasing at the highest molarities. The higher lamp power clearly provides sufficient photo-generated electron-hole pairs to promote the oxidation-reduction reaction necessary at the GaN surface. Higher etch rates 
were obtained when the sample was biased, consistent with past data on $\mathrm{SiC} .^{(5)}$ The $\mathrm{n}^{+}$ $\mathrm{GaN}$ did not etch at all over a broad range of $\mathrm{KOH}$ concentrations $(0.005-1 \mathrm{M})$ when no Ti metal contact was present on the sample, probably due to the inability to separate e-h pairs under these conditions. Similarly, InN was also not etched in these experiments, possibly as a result of the high intrinsic electron concentration in the material. It is difficult to create enough extrinsic carriers to promote the dissociative oxidation of this material. The roll-off of etch rate at high $\mathrm{KOH}$ solution molarity in Figure 2 is probably due to excessive oxide formation on the surface. ${ }^{(16)}$

The temperature dependence of $\mathrm{n}-\mathrm{GaN}$ etch rate in $0.05 \mathrm{M} \mathrm{KOH}$ solutions without applied bias is shown at the top of Figure 3. As expected, the GaN dissolution occurs faster at elevated temperatures. As Arrhenius plot of the data (bottom of Figure 3) reveals an activation energy of $\sim 0.8 \mathrm{kCal} \cdot \mathrm{mol}^{-1}$. This is typical of diffusion-limited etching, whose other characteristics are a square-root dependence of etch rate on time, relatively rough surfaces and a strong dependence of rate on solution agitation. This is consistent with the results of Youtsey et. al. ${ }^{(11)}$

AFM scans of the etched n-GaN surface morphology are shown in Figure 4. The etched surfaces are rougher than those of the control sample under all the conditions we examined. This is fairly typical of photo-enhanced etching of semiconductors, and only Youtsey et. al. have reported a small window of conditions where good morphologies for GaN were achieved. ${ }^{(12)}$ Figure 5 shows the root-mean-square surface roughness measured by AFM and normalized to that of the control sample, as a function of $\mathrm{KOH}$ solution molarity. The best surfaces were obtained at either low or high molarities. 
Some typical features formed in $\mathrm{n}^{+} \mathrm{GaN}$ using a $0.01 \mathrm{M} \mathrm{KOH}$ solution at $25^{\circ} \mathrm{C}$ (450W of $\mathrm{Hg}$ lamp power) are shown in the SEM micrographs of Figure 6. The rough morphologies are typical of those reported previously for $\mathrm{GaN}^{(11,13,15,16)}$ and $\mathrm{SiC}^{(6)}$, and probably represent the micro-crystallites in the material. ${ }^{(14)}$ We believe the PEC process is useful only in particular device fabrication steps where morphology will not be an issue. These would include mesa isolation of electronic devices, selective removal of $\mathrm{n}$ type GaN from an underlying $\mathrm{p}-\mathrm{GaN}$ layer (such as in revealing the base region of a heterojunction bipolar transistor) or in shallow etch situations, such as removal of dry etch damage.

AES surface scans of an unetched GaN control sample (top) and one etched at $25^{\circ} \mathrm{C}$ in a $0.01 \mathrm{M} \mathrm{KOH}$ solution (bottom) are shown in Figure 7. The Ga-to-N ratios are approximately the same, indicating that $\mathrm{Ga}$ and $\mathrm{N}$ are removed at essentially the same rate during the PEC process. Notable is the fact that there is more oxygen detected on the etched sample, consistent with the expected etch mechanism.

\section{SUMMARY AND CONCLUSIONS}

PEC etching is found to selectively reveal grain boundaries in GaN under low light illumination conditions. At high lamp powers the rates increase with sample temperature and the application of bias to the PEC cell, while they go through a maximum with $\mathrm{KOH}$ solution molarity. The etching is diffusion-limited, producing rough surface morphologies that are suitable in a limited number of device fabrication steps. The surfaces however appear to remain relatively close to their stoichiometric composition. 


\section{ACKNOWLEDGMENTS}

The work at UF is partially supported by DARPA/EPRI contract (E. Brown / J. Melcher), No. MDA 972-98-1-0006. The work of H.C. is also partially supported by KOSEF. Sandia is a multiprogram laboratory бperated by Sandia Corporation, a Lockheed-Martin company for the US Department of Energy under contract DEAC04-95 AL 85000. 


\section{References}

1. J. van de Ven and H.J.P. Nabben, J. Electrochem. Soc. 1371603 (1990).

2. M.N. Ruberto, X. Zhang, R. Scarmozzino, A.E. Willner, D.V. Podlesnik, and R.M. Osgood, Jr., J. Electrochem. Soc. 1381174 (1991).

3. R. Khare and E.L. Hu, J. Electrochem. Soc. 1381516 (1991).

4. J.S. Shor, R.M. Osgood and A.D. Kurtz, Appl. Phys. Lett. (1992).

5. J.S. Shor, X.G. Zhang and R.M. Osgood, J. Electrochem. Soc. 139 (1992).

6. J.S. Shor and R.M. Osgood, Jr., J. Electrochem. Soc. 140 (1993).

7. F.W. Ostermayer and P.A. Kohl, Appl. Phys. Lett. $\underline{39} 76$ (1981).

8. M.J. Grove, D.A. Hudson, P.S. Zory, R.J. Dalby, C.M. Harding and A. Rosenberg, J. Appl. Phys. 76587 (1994).

9. M.S. Minsky, M. White and E.L. Hu, Appl. Phys. Lett. $\underline{68} 1531$ (1996).

10. C. Youtsey, I. Adesida and G. Bulman, Electron. Lett. $\underline{33} 245$ (1997).

11. C. Youtsey, I. Adesida and G. Bulman, App1. Phys. Lett. 712151 (1997).

12. C. Youtsey, I. Adesida, L.T. Romano and G. Bulman, Appl. Phys. Lett. $\underline{72} 560$ (1998).

13. C. Youtsey, G. Bulman and I. Adesida, J. Electron. Mater. 27282 (1998).

14. C. Youtsey, L.T. Romano and I. Adesida, Appl. Phys. Lett. 73797 (1998).

15. H. Lu, Z. Wu and I. Bhat, J. Electrochem. Soc. 144 L8 (1997).

16. L.-H. Peng, C.-W. Chuang, J.-K. Ho, C.N. Huang and C.-Y. Chen, Appl. Phys. Lett. $\underline{72} 939$ (1998).

17. J. O, P.S. Zory and D.P. Bour, SPIE Proc. $\underline{3002} 117$ (1997). 
18. C.B. Vartuli, S.J. Pearton, C.R. Abernathy, J.D. MacKenzie, F. Ren, J.C. Zolper and R.J. Shul, Solid-State Electon. 411944 (1997).

19. A. Shintani and S. Minagawa, J. Electrochem. Soc. 123707 (1976).

20. T. Kozawa, T. Kachi, T. Ohwaki, Y. Tager, N. Koide and M. Koike, J. Electrochem. Soc. 143 L17 (1996).

21. D.A. Stocker, E.F. Schubert and J.M. Redwing, Appl. Phys. Lett. (in press).

22. B.J. Kim, J.W. Lee, H.S. Park, Y. Park and T.I. Kim, J. Electron. Mater. 27 L32 (1998). 
Figure Captions

Figure 1. Optical micrographs of GaN surfaces after PEC etching at low illumination powers, magnification $\times 50$ (top) and $\times 1000$ (bottom).

Figure 2. Etch rate of $\mathrm{n}^{+}$and non-intentionally-doped (NID) GaN, either with or without $1.5 \mathrm{~V}$ bias, in $\mathrm{KOH}$ solutions at $25^{\circ} \mathrm{C}$ as a function of solution molarity.

Figure 3. Temperature dependence (top) and Arrhenius plot (bottom) of GaN PEC etch rate in $0.05 \mathrm{M} \mathrm{KOH}$ solutions without biasing of the sample.

Figure 4. AFM scans of $\mathrm{GaN}$ before and after $\mathrm{PEC}$ etching without bias in $\mathrm{KOH}$ solutions of different molarities.

Figure 5. Normalized surface roughness (control sample has a value of 1) of PEC etched $\mathrm{GaN}$ as a function of $\mathrm{KOH}$ solution molarity.

Figure 6. Features etched into $\mathrm{n}^{+} \mathrm{GaN}$ using $0.01 \mathrm{M} \mathrm{KOH}$ solution at $25^{\circ} \mathrm{C}$.

Figure 7. AES surface scans of $\mathrm{GaN}$ before (top) and after PEC etching in $0.01 \mathrm{M} \mathrm{KOH}$ solution at $25^{\circ} \mathrm{C}$. 

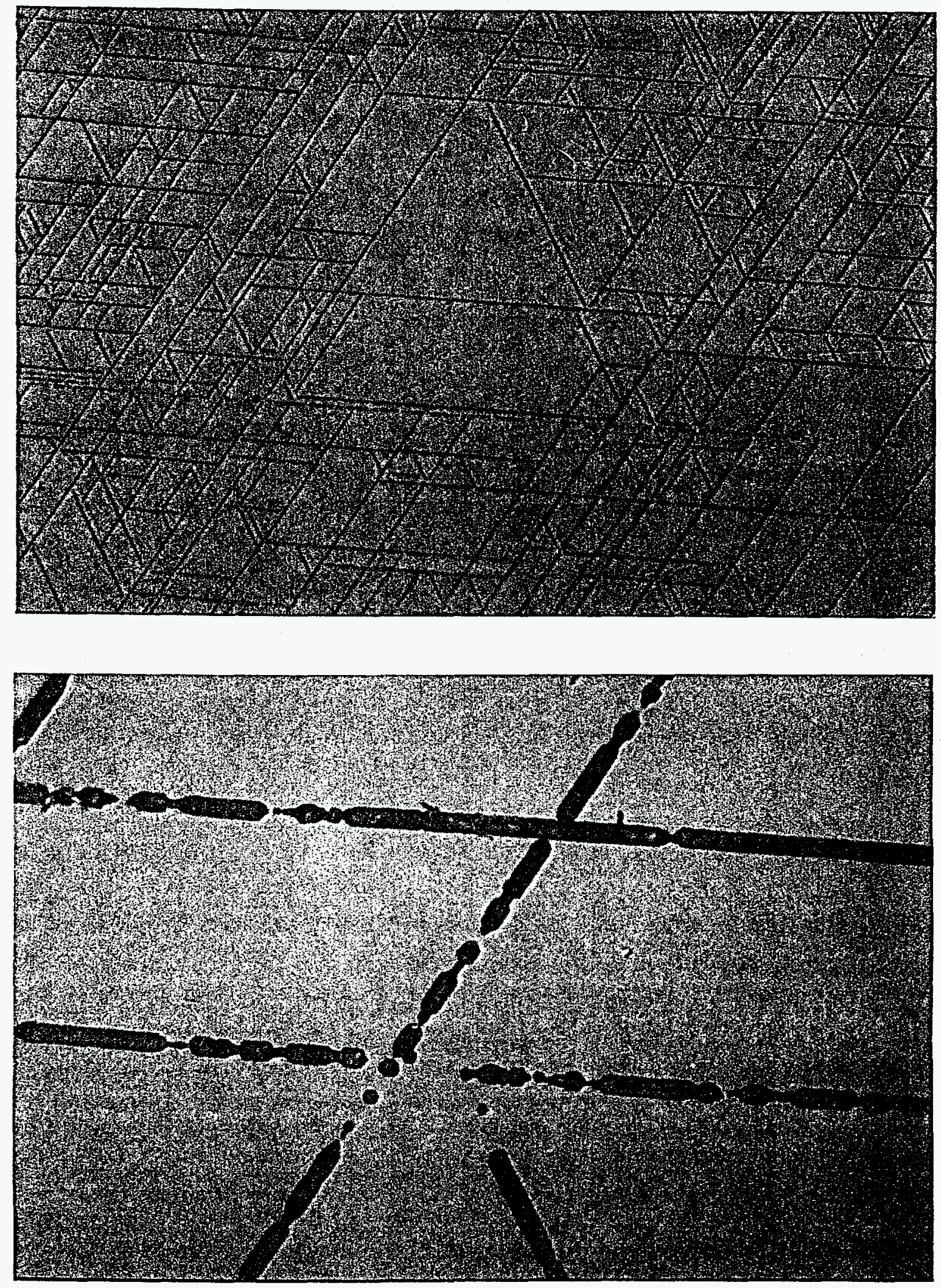


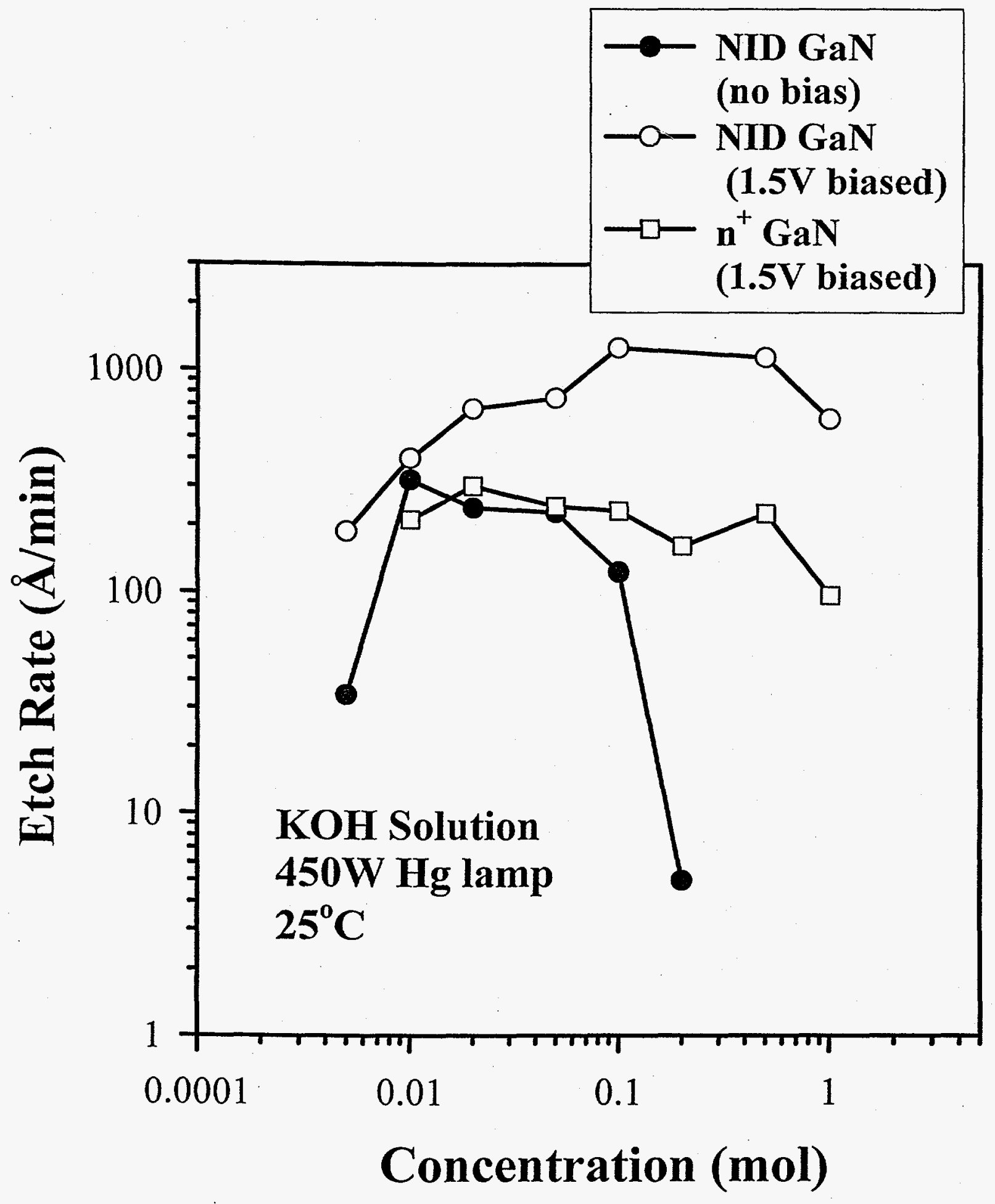



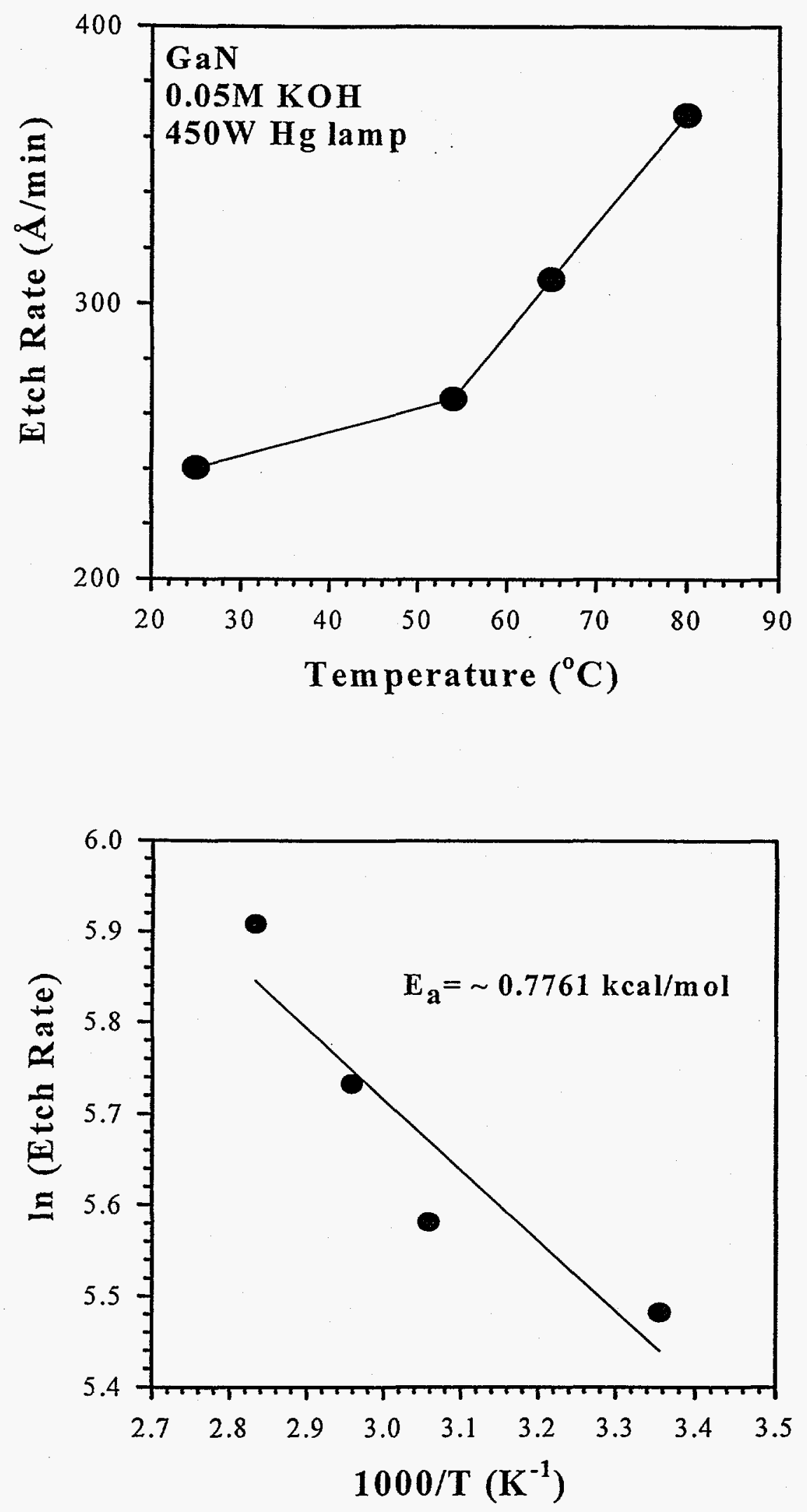


\section{GaN \\ 450W Hg lamp, $25^{\circ} \mathrm{C}$}

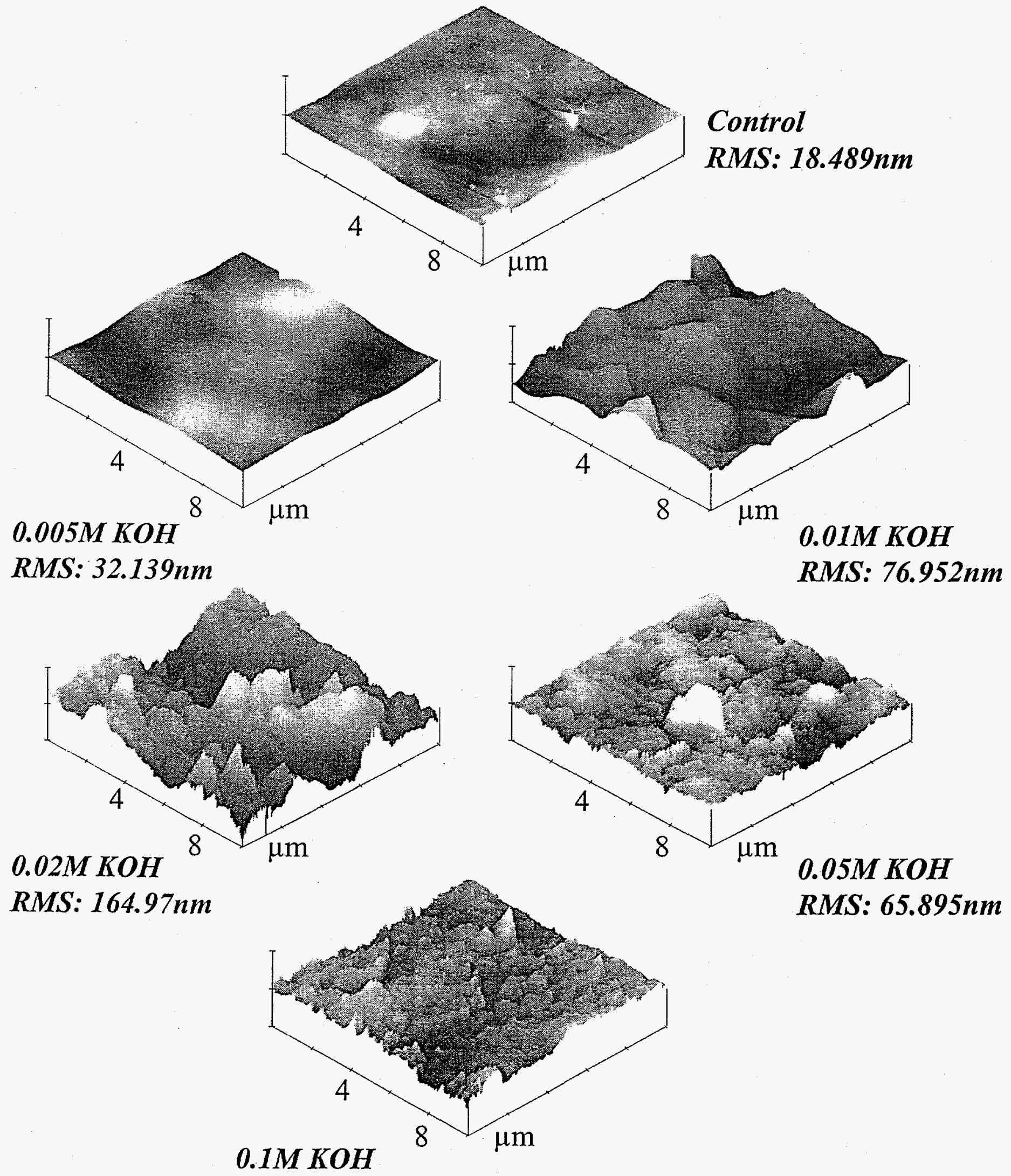




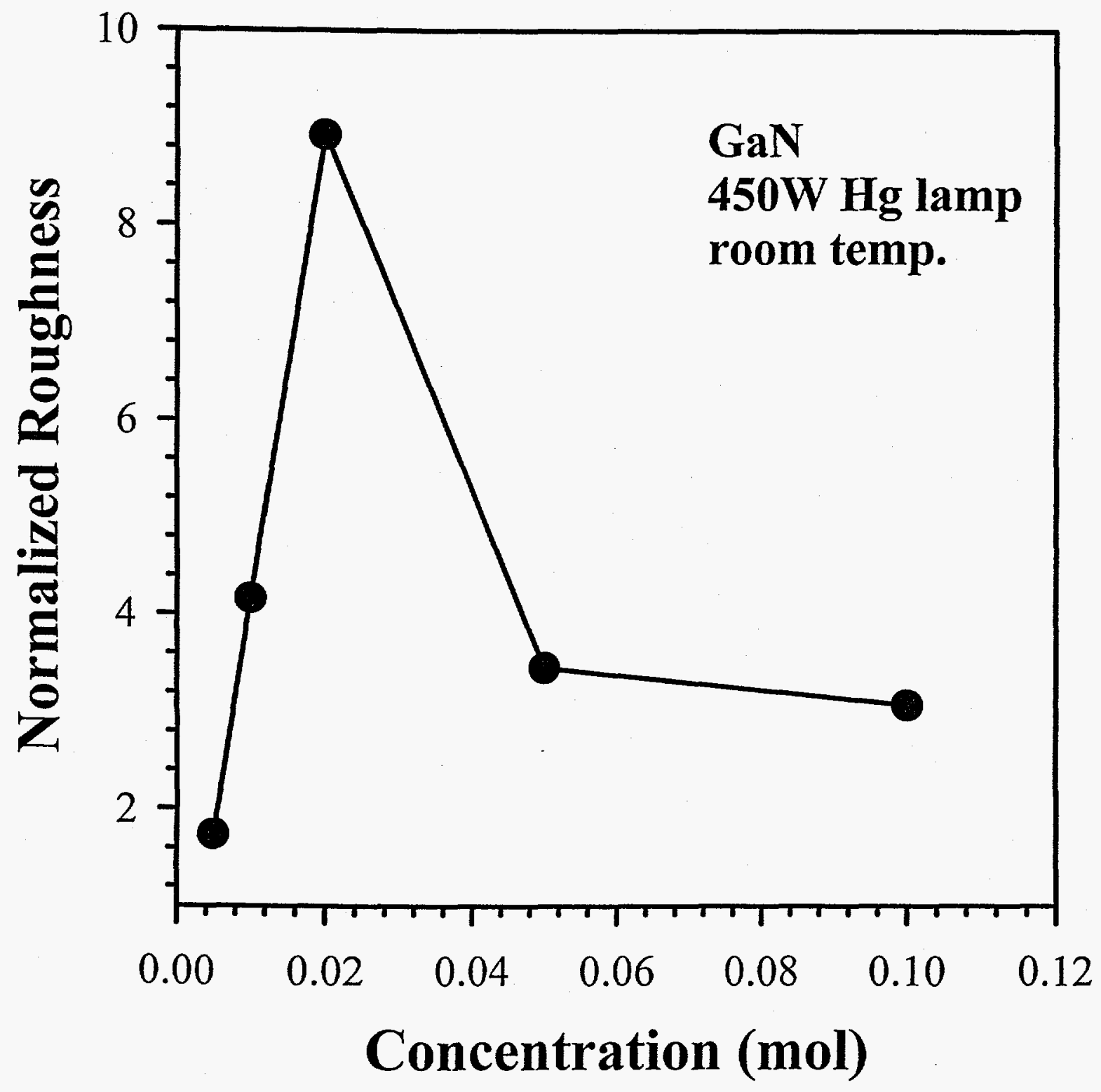



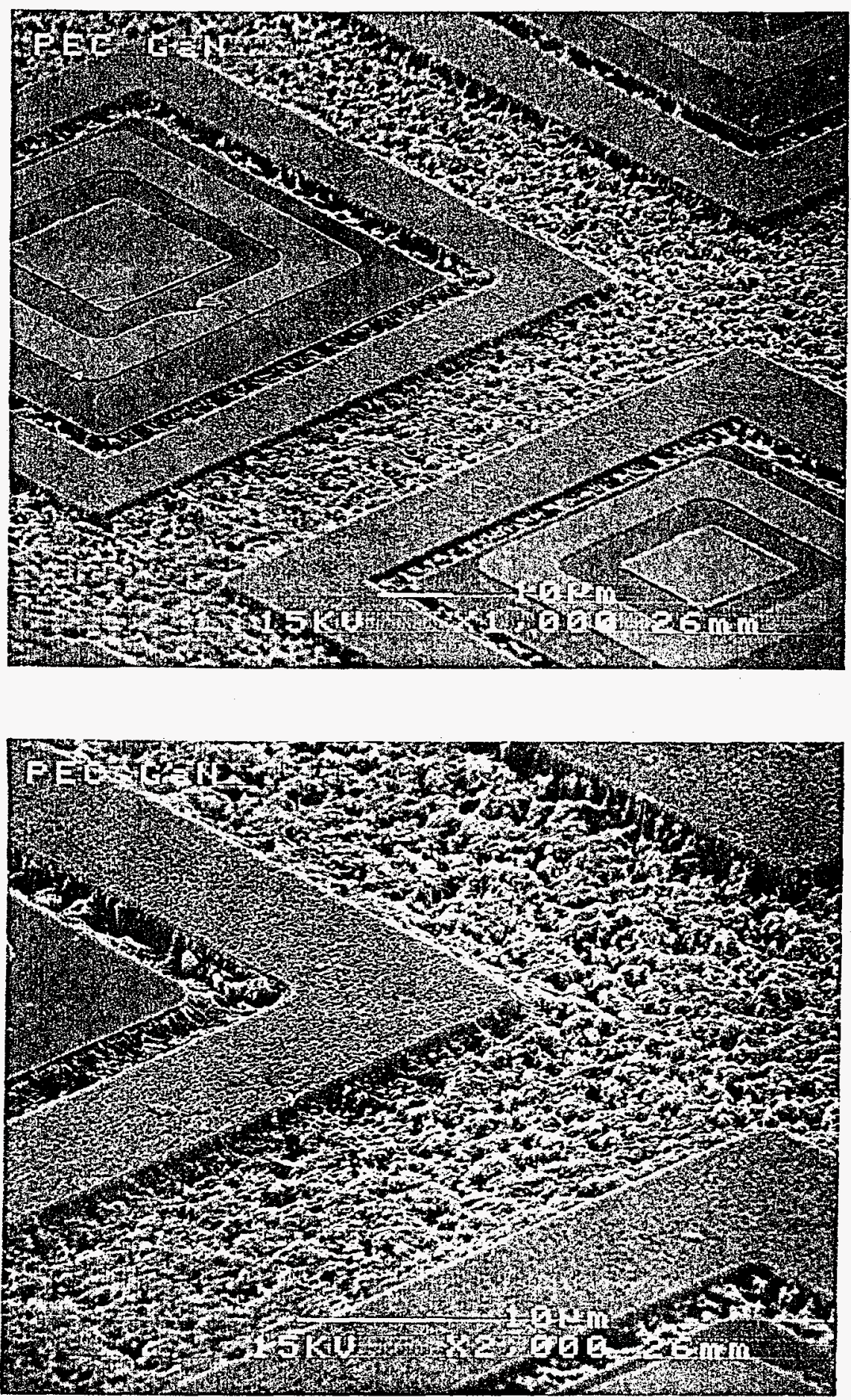

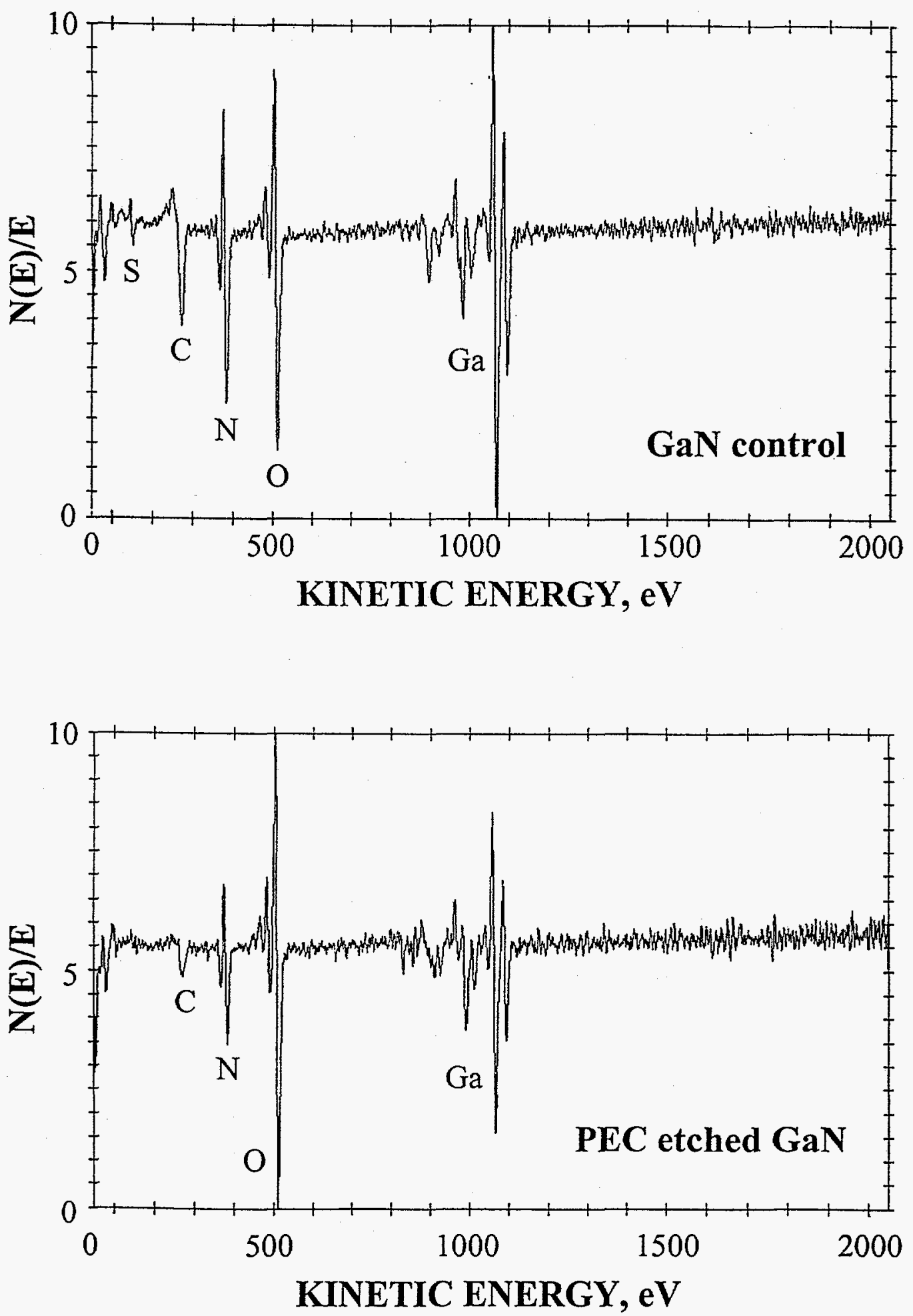